\title{
THE BIO-MEDICAL PURSUITS OF CHRISTOPHER WREN*
}

by

\section{WILLIAM CARLETON GIBSON}

IN A YEAR characterized by men walking about on the moon, some will ask why we should concern ourselves with the exploits of a great architect, once a geometer and mathematician, an astronomer, the father of blood transfusion and above all-a great public servant. My answer is simply that in the commemoration of another great citizen-scientist, Dr. Sydney Monckton Copeman, a physician with universal interests, nothing is more fitting than a recital of those parts of Christopher Wren's career which betray a life-long interest in biology and medicine, too often overlooked by his admirers.

Nor is this year of men landing on the moon foreign to the interests of our good Christopher Wren, for he was a child of six years, at Windsor, when in 1638 his friend and mentor there, the Reverend John Wilkins published his famous Discovery of a World in the Moon. After discussing such problems as a 'motive faculty to overcome gravity', and 'the cold rarified atmosphere', Wilkins says, so prophetically: 'Tis likely enough that there may be a means invented of journying to the Moone; And how happy shall they be, that are first successful in this attempt' (See fig. 3).

It is no accident therefore, that when Wren, as an Oxford undergraduate, came under the tutelage of Warden Wilkins at Wadham College, they should combine forces to produce a telescope eighty feet long, as they said, 'to see at once the whole moon'. Nor do we find it strange that the youthful Wren should produce the first lunar globe in history-now lost to science, alas. From his earliest years this 'miracle of a youth', as John Evelyn called him, gave every promise of being the British Leonardo. Beginning life as a most delicate child, he nevertheless lived into his ninety-first year, a model of the creatively curious mind-a builder of instruments, churches and cities, an artist and practical philosopher.

I suppose that anyone who reads the English language sooner or later crosses the path of Christopher Wren. A meteorologist, an astronomer, an architect, a nutritionist or a town-planner will know something of that great contributor to our culture. My own interest in Wren's life dates from my first meeting in 1935 with my teacher at Oxford, Sir Charles Sherrington. He told me that he had given to the president of my home university in Vancouver, Dr. F. F. Wesbrook-twenty years previously -a copy of Bidloo's great copper-plate anatomy of 1685 . During the long vacation from Oxford in $1936 \mathrm{I}$ had started to work in Rio-Hortega's summer laboratory on the north coast of Spain at Santander, when the Spanish Civil War erupted. Since no studies seemed possible in those circumstances I returned to British Columbia for

- The Monckton Copeman Lecture of the Faculty of the History of Medicine and Pharmacy, Worshipful Society of Apothecaries of London, read at the Wellcome Institute of the History of Medicine 4 March 1970. 


\section{W. C. Gibson}

a visit, and found in the vault of the University Library the well-preserved copy of Bidloo mentioned earlier by Sherrington. To my amazement I found that this copy had belonged to Nicholas Hawksmoor, the distinguished pupil of Wren. It had been acquired by Hawskmoor eight years after it appeared in Amsterdam. Sherrington, who bought the book in Cambridge in 1887, covered one of the end-papers with neatlywritten notes, telling of Hawksmoor's association with Wren, and of the assistance which he had rendered Wren on some of his larger undertakings. When I commented upon this ownership to Sir Charles later, I was ushered into a far more wonderful story, that of Wren's pre-architectural and pre-astronomical life in medical science. This was liberally spiced with details of the life of Thomas Willis, who, in Sherrington's view, had changed neurology from a speculative to a rational science. Wren had assisted Willis in his studies of the brain at Oxford, both as dissector and illustrator, so that I began to read about Wren and to listen to Dr. Robert Gunther lecture at Oxford on the origins of the Royal Society.

Wren was born into a family closely associated with the religious and scholarly life of Britain. His father was educated at Oxford, where he had served as Senior Proctor. Though Dean of Windsor, he was both mathematician and architect by avocation. His son was born in 1632, as were van Leeuwenhoek and Spinoza. Galileo's Dialogue was published in the same year. Also in the year of Wren's birth, Charles Scarburgh was about to enter Caius College, Cambridge, where his father and grandfather had been educated before him. This youth was destined to study medicine in Harvey's college and to be driven out of Cambridge as a Royalist, losing both his fellowship and his library-and having to flee to Oxford where he 'attached himself to Harvey at Merton'. The Court, in exile, occupied much of that college, but Scarburgh and Harvey found a place to work 'in the little chamber beyond the library'. Scarburgh assisted Harvey in many of his investigations, and it is possible that he acquired then an interest in the muscular system. His only publication was on the muscles, long after he had succeeded Harvey as Lumleian Lecturer at the Royal College of Physicians. Certain it is that Scarburgh was busy with Harvey and George Bathurst on embryological research at Merton, and also in Bathurst's college, Trinity, Oxford. There they had the service of a hen which hatched eggs that were opened daily to follow the various stages of embryological development.

It is not clear whether Christopher Wren ever met Harvey in Oxford, My former colleague in Rio-Hortega's laboratory in Madrid, Dr. Alastair Robb-Smith, has become a specialist on Harvey's short years at Oxford, and has kindly provided me with the evidence which suggests the possibility that Wren could have known Harvey. But far more important than this is the certain and decisive influence of Sir Charles Scarburgh on the fifteen-year-old boy, who had just left Westminster School, and was living only a few miles outside Oxford at the village of Bletchington, to which the senior Wren had retired, as his son-in-law Dr. William Holder had been appointed Rector there. Scarburgh suggested that Wren should translate into Latin, the chapter in William Oughtred's Clavis Mathematicae on 'dialing', or the design of sun-dials. It is little wonder therefore that we find today two examples of his early sun-dials at Bletchington. Better known, of course, is his massive and multi-coloured dial on the wall of the quadrangle in All Souls College, Oxford. Oughtred was so 


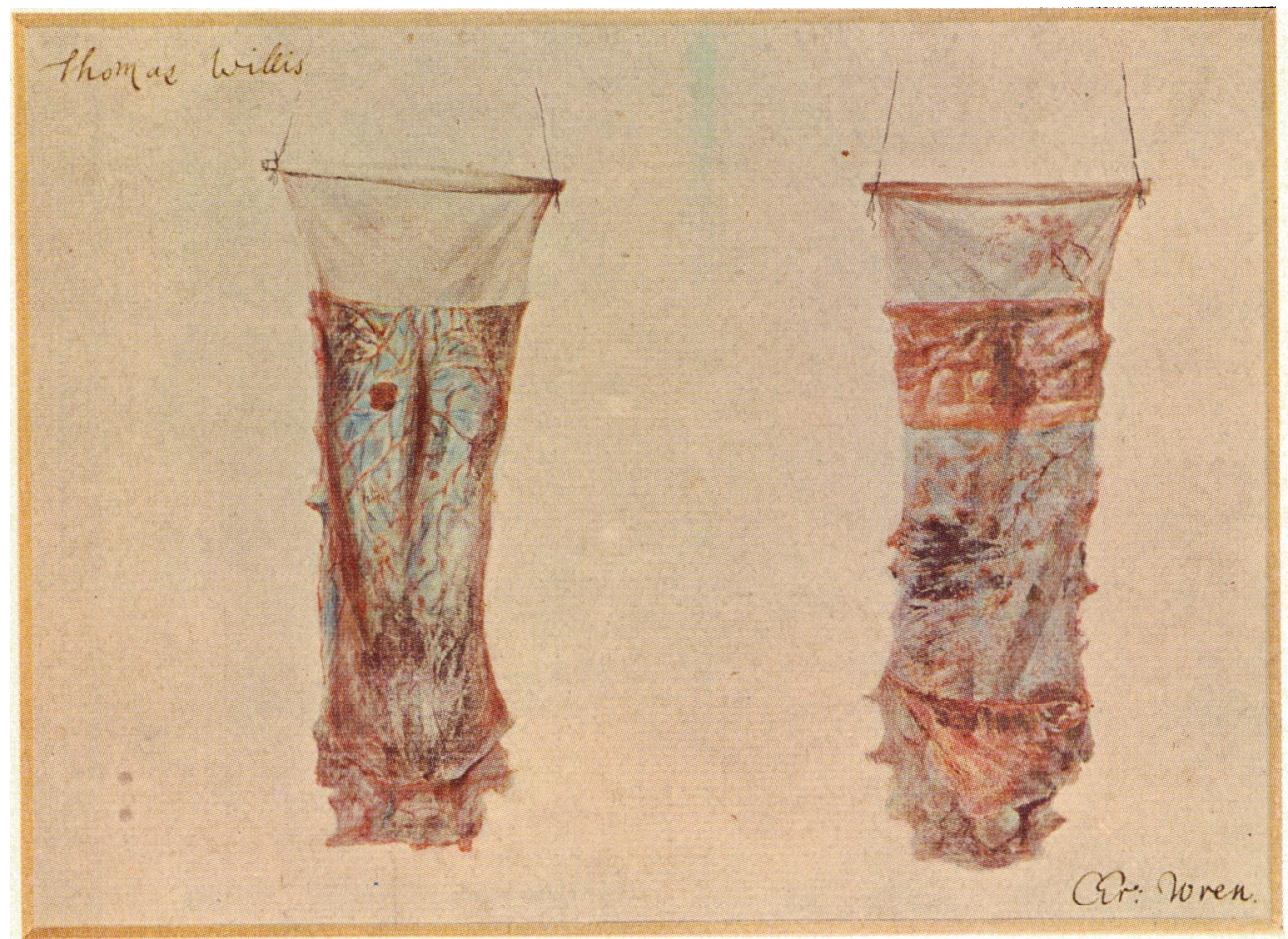

(By courtesy of the Wellcome Trustees.)

Plate 1

Anatomical watercolour signed at the bottom by Sir Christopher Wren and in the left upper corner by Thomas Willis. Original in the possession of the Wellcome Institute of the History of Medicine. 

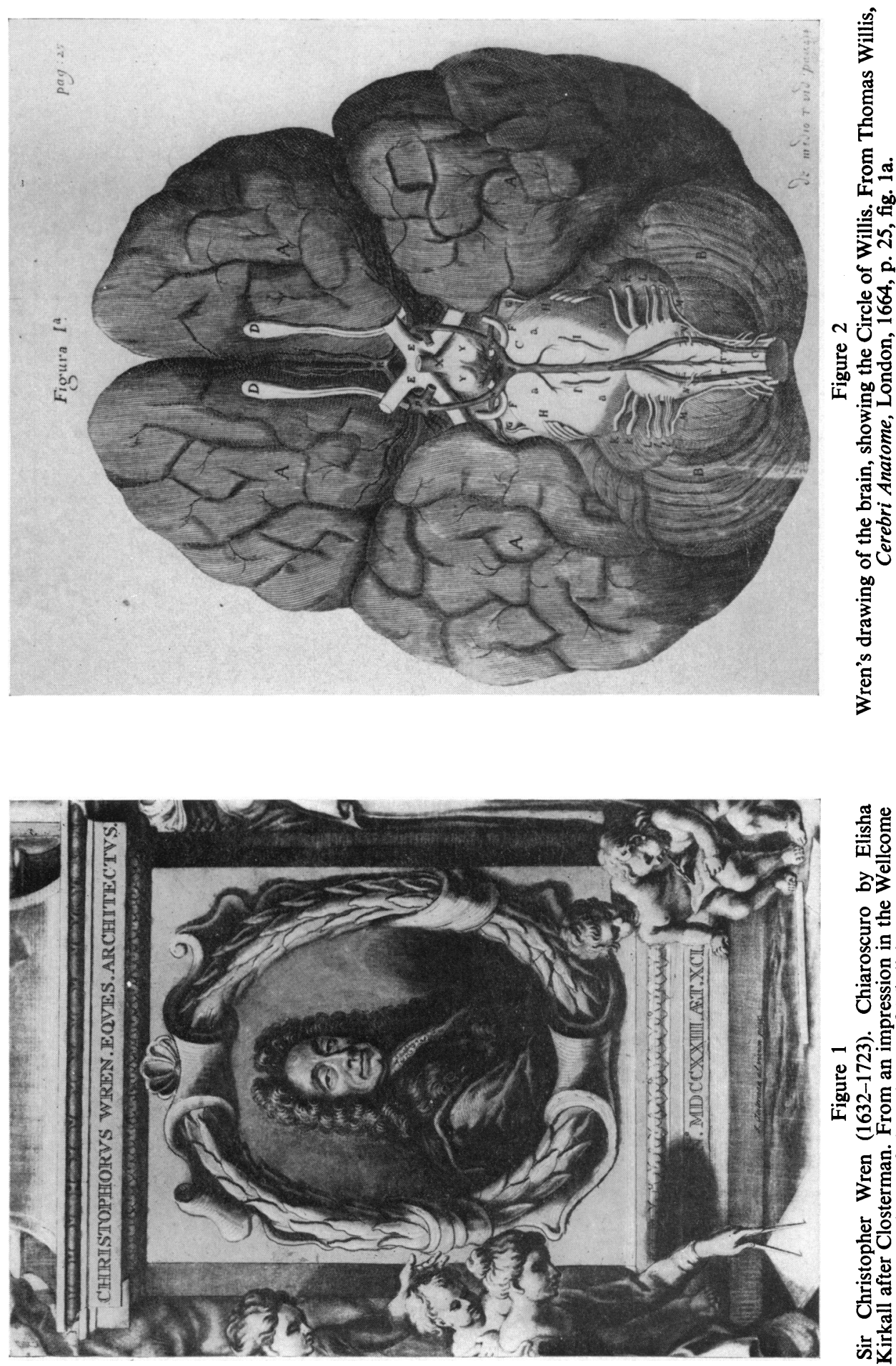

풀

육롱.

氙.

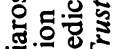
㐘.율 穴.

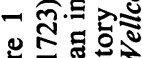
든 总

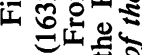

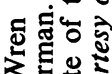

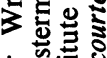

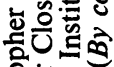
원 氞密 ธี 部 


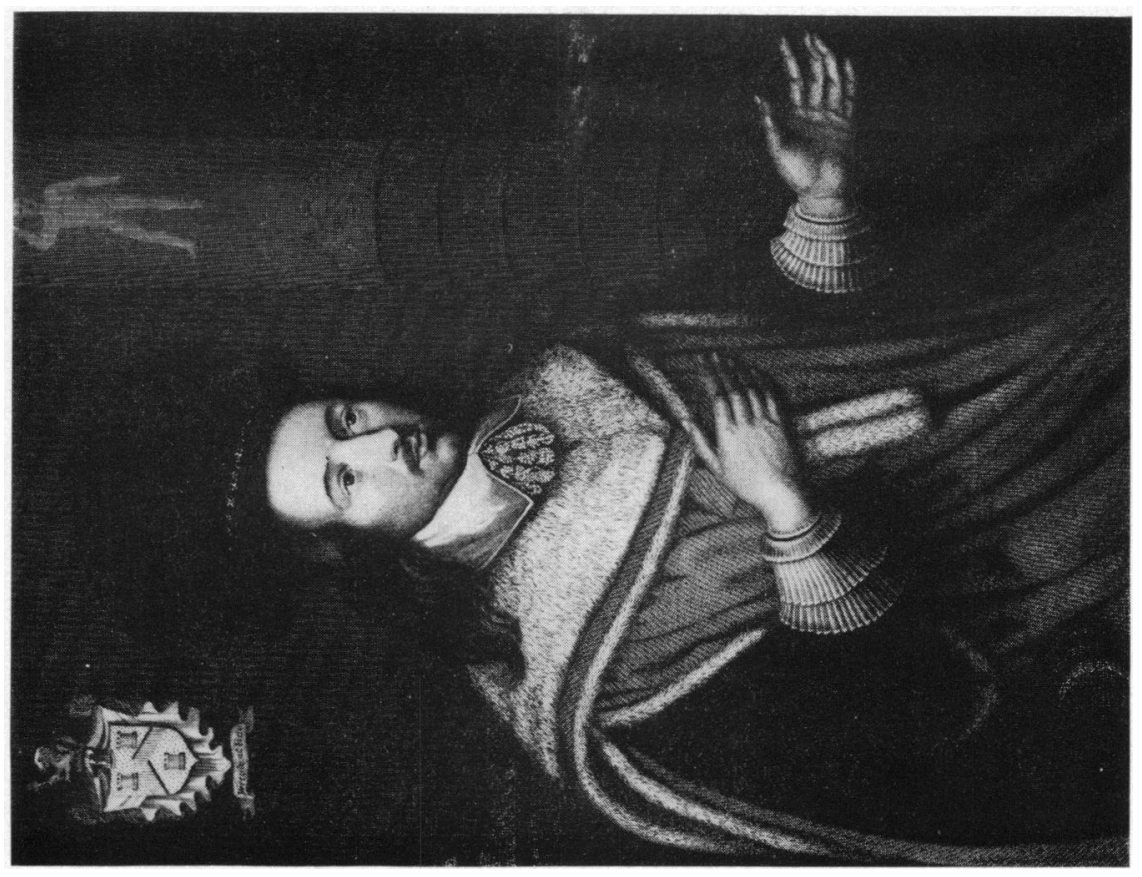

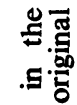

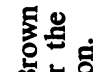

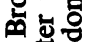

泡

วิ.

00. 争

s.

त्र

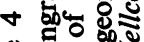

回入界

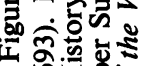

인은

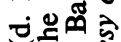
ᄃक 입. 웡 ํㅗㄴ 为淧 要专

so

ํํㄴ

U。

部

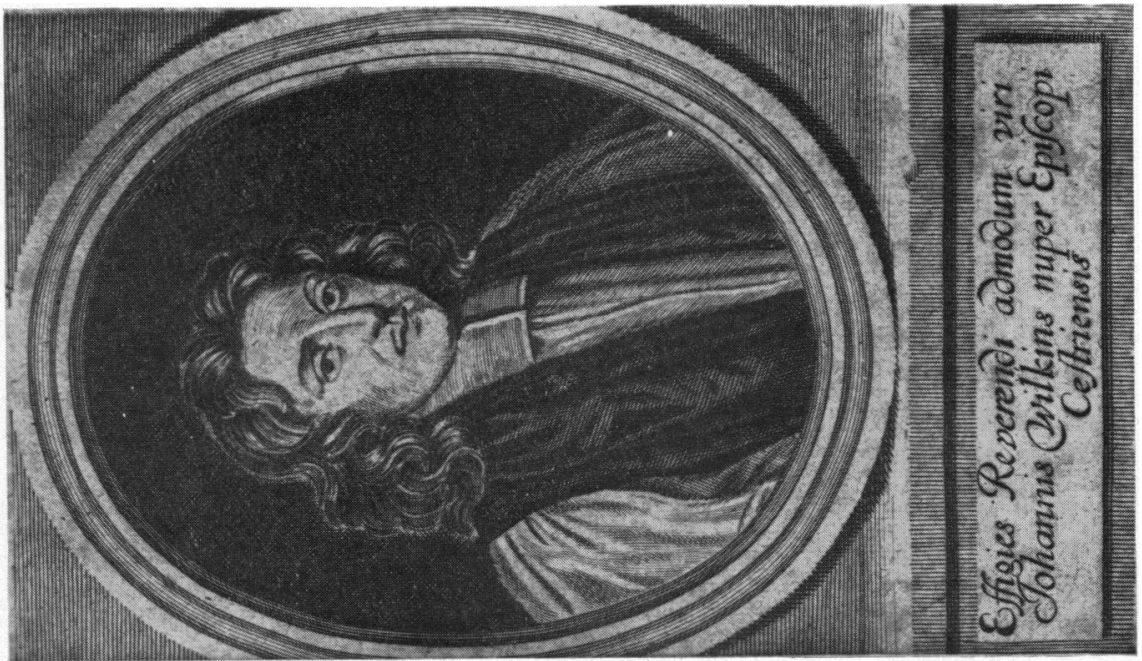

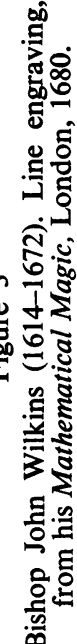




\section{The Bio-medical Pursuits of Christopher Wren}

impressed by the youthful Wren that he described him as: 'A young man of marvellous gifts who when not yet sixteen years of age, advanced astronomy, gnomonics, statics, and mechanics by his distinguished discoveries, and from then on continues to advance these sciences. And truly he is the kind of man from whom I can shortly expect great things, and not in vain.'

At the age of fifteen years, Wren wrote to his father that he had been befriended by Scarburgh (fig. 4) who lent 'a patient ear to my poor Reasonings'. Furthermore, Scarburgh was Wren's physician and cured him 'from recent sickness ... as from the hand of God'. The account of Wren's life given by his son in Parentalia says that he 'composed a Treatise on the Motion of Muscles, explaining the whole Anatomy by Models form'd in Pasteboards. These were presented to Sir Charles Scarburgh, but lost at the Fire of London'.

In his incomparable biography of William Harvey, Sir Geoffrey Keynes traces a line of 'mental continuity' in the vascular field, from Harvey, to Scarburgh to Wren. It may be that in the field of muscles of the body, the continuity is still more progressive. Scarburgh's only publication, Syllabus Musculorum, summarized his demonstrations given at Surgeon's Hall in London, from 1649 to 1666. Proceeding backwards in time, Scarburgh's teacher, William Harvey, tells us 'I also intended putting to press ... from observations in my possession' a work on Organs of Motion in Animals, extracts of which were published only in 1850 by Sir George Paget. Harvey's famous Paduan teacher, Fabricius of Aquapendente, had also published a volume of De Musculi Animalis. Fabricius learned his anatomy at the knee of Fallopius, the loyal pupil of Vesalius, whose 'muscle men' in the first edition of the Fabrica in 1543, set a new standard in anatomy. Imagine the delight which Osler experienced during his visit to Padua on seeing not only the anatomy theatre given to the university by Fabricius, but more intimately, Fabricius' own copy of Vesalius' Fabrica of 1543. Osler said: 'I am sorry that I had not an option, as I should have liked to have been prosector to Fabricius.'

At the risk of stretching, to the point of tetany, the muscle fibrils binding together Wren and his spiritual forebearers, let me mention that Wren's contemporary William Croone, who succeeded Scarburgh at Surgeon's Hall in 1670, read 'the theory of muscular motion' there for several years, and is still memorialized by the Croonian Lecture at the Royal Society 'upon the nature and laws of muscular motion'.

To return to Oxford we find Christopher Wren, at the age of seventeen, entering Wadham College. There Wren continued to make instruments, paste-board anatomical models, and even transparent bee-hives, 'built like castles and palaces', in the words of John Evelyn the diarist. Scarburgh provided the funds to enable Wren to construct his first 'weather clock'-an instrument which he was to return to and refine years later. The year 1653 saw the publishing of the first English edition of Harvey on the circulation, and found Wren a newly-elected Fellow of All Souls, the 'post-graduate' college, if we may use such a designation, built in 1438 as a memorial to 'All the Souls of the Faithful Departed'. John Evelyn tells us of an Oxford visit at that time: 'After dinner I visited that miracle of a youth Mr. Christopher Wren, a nephew of the Bishop of Ely'. Two days later Evelyn visited Wadham College, nearby: 'We all din'd at the most obliging and universally curious Dr. Wilkins's'. On that occasion he saw an 
extensive collection of working models, some of which Wren had created. Alas, according to the present Warden, Sir Maurice Bowra, none of these remains. Some were astronomical, and in particular there was what Wren called 'a pneumatic engine' which led Boyle, by way of early barometers, to a life-long interest in gases and the reciprocal relationship between their volume and pressure.

Harvey's views on the circulation were strongly discernible in Scarburgh, who transmitted them to Wren, so that by the age of twenty-four Wren was turning over in his mind the possibility of injecting substances-poisons for instance-directly into the bloodstream of animals. Having told Wilkins and Boyle of this hope, Wren made the great forward leap-the invention of intra-venous therapy-which has so greatly changed contemporary practice. It was a logical but bold development arising from Harvey's teachings. Boyle tells us clearly of the exposure of a suitably large superficial vein in the hindleg of a dog, followed by the surface application of a small grooved plate (of Wren's own manufacture) to hold the vein from moving laterally. Boyle's description of Wren's work continues:

... he made a slit along the vein, from the ligature towards the Heart, great enough to [admit] the slender pipe of a Syringe; by which I had proposed to have injected a warm solution of Opium in Sack, that the Effect of our Experiment might be the more quick and manifest. And accordingly our dexterous Experimenter ... . conveyed a small Dose of the Solution or Tincture into the opened vessel, whereby setting into the Mass of Blood. . . . It was quickly, by the circular of that, carried to the Brain, and other Parts of the Body: So that we had scarce untied the Dog... before the opium began to disclose its Narcotick quality, and almost as soon as he was on his feet he began to nod with his head, and falter and reel in his Pace, and presently after appeared so stupified, that there were Wagers offered his Life could not be saved ... he not only recovered but began to grow fat so manifestly that 'twas admired: But I could not long observe how it fared him: For this Experiment ... having made him famous, he was soon after stolen away from me.

Wren's own description, written to Sir William Petty in Ireland, is briefer and more clinically orientated. He wrote:

The most considerable experiment I have made of late is this: I injected wine and ale into the mass of blood in a living dog, by a vein, in good quantities, till he became extremely drunk; but soon after voided it by urine. It will be too long to tell you the effects of opium, scammony and other things which I have tried in this way. I am in further pursuit of the experiment, which I take to be of great concernment, and what will give great light to the theory and practice of physic.

How clearly Wren saw the new vistas opened up by his 'experiment'! As Keynes points out in his definitive study of Harvey, Wren's triumph inspired Lower to try blood transfusion. Wren's priority is substantiated by Robert Boyle and by Henry Oldenburg, the Secretary of the Royal Society who had occasion to mention it years later in Royal Society discussions. Sprat supports this evidence in the following reference to Wren in his History of the Royal Society:

He was the first Author of the Noble Anatomical Experiment of Injecting Liquors into the Veins of Animals. An Experiment now vulgarly known, but long since exhibited to the Meetings at Oxford. .... By this Operation divers Creatures were immediately purg'd, vomited, intoxicated, killed or reviv'd, according to the quality of the Liquor injected. Hence arose many new Experiments, and chiefly that of Transfusing Blood, which the Society has prosecuted in sundry Instances, that will probably end in extraordinary success. 


\section{The Bio-medical Pursuits of Christopher Wren}

In 1657, the year of Harvey's death, Wren was being transferred to London as the youthful Gresham Professor of Astronomy. His inaugural lecture is incredible for the breadth of vision to which it exposed his largely lay audience. They were transported in celestial directions with superb oratory, but at the same time they heard from Wren of the need to study diseases and the weather. He asked his hearers to think back to Hippocrates' 'Aphorisms', and advocated the study of 'the History of Pests, and epidemical Diseases . . . which would be of admirable use to Physick'. He could not miss an opportunity to bring his revered physician-heroes, Harvey and William Gilbert, into this discourse. To do this he began by saying:

Now the Learned begin to be warm, the Schools ring with Dispute . . . some of them . . . begin to observe Nature, and to dare to support old Opinions false; and now began the first happy Appearance of Liberty to Philosophy . . .. Among the honourable Assertors of this Liberty, I must reckon Gilbert, who ... found . . . the great Magnet of the Earth. ... This Man would I have adored, not only as the sole Inventor of Magneticks a new Science to be added to the Bulk of Learning, but as the Father of the new Philosophy. . . . This person I should have commended to Posterity in a Statue, that the deserv'd marble of Harvey might not stand to future Ages, without a Marble Companion of his own Profession.

In passing, Wren told his audience of the 'real Science of Nature' which the microscope and the telescope were opening to man's gaze. He said: ' ... imagine how much the ancient laborious Enquirers would envy us should he [Seneca] have sung to them that a Time would come, when Men should be able to stretch out their Eyes, as Snails do, and extend them to fifty Feet in Length; . . . and every nebulous Star appearing as if it were the Firmament of some other World, at an incomprehensible Distance, bury'd in the vast Abyss of intermundious Vacuum.' I would remind you that a man of only twenty-five years of age is speaking. Nevertheless Wren was not blinded by his own production, for he wrote to his old Wadham friend Bathurst-by now President of Trinity College, Oxford: 'I am convinced with Machiavel . . . that the world is generally governed by words.'

On 28 November 1660, after Wren's 'Wednesday lecture' at Gresham College, fourteen men, of whom a good proportion were physicians, met to form the Royal Society. They were eventually to include the equally youthful John Locke the physician-philosopher, William Petty, Robert Boyle and Dr. Croone. Wren wrote the 'Preamble of a Charter to incorporate the Royal Society'. In it he refers to 'the Advancement of Natural Experimental Philosophy ... by the Addition of useful Inventions tending to the Ease, Profit, or Health of our Subjects'. 'A number of Persons of eminent Learning, Ingenuity and Honour' were 'orderly to confer about the hidden Causes of Things' and 'to approve themselves real Benefactors to Mankind'. Medicine, or Physick, was named as one of the fields of endeavour, and the Just Society was envisaged, with, as Wren said, 'Wealth and Plenty diffused in just Proportion to every one's Industry'. In the same year Wren was appointed Savilian Professor of Astronomy at Oxford, succeeding his Wadham friend Seth Wardlater Bishop of Salisbury. Thus he returned to Oxford to embark on another series of experiments-or, as I suppose they seemed to him-adventures.

Wren's greatest surgical success was the removal of the spleen in dogs followed by years of useful survival. Professor John Fulton has commented on Wren's surgical 


\title{
W. C. Gibson
}

technique, feeling that what he used to dress the wound, was certainly an antiseptic and possibly an antibiotic mixture. Wren's description of his 'Operation and Method of Cure' in the removal of the spleen, was a model of precision in the surgical anatomy involved, pitfalls and their avoidance, and the solicitous care of the dog 'exempted' of his spleen. The prescription for the drugs required in the dressing of the operation site are all written in the exact pharmaceutical terms which a physician would employ. Wren's writing in this account is a revelation in its display of expertise. In the siting of the incision Wren explains the landmarks clearly, and warns the operator to have 'a Care of the Guts', and to

\begin{abstract}
draw out the spleen just without the Wound, having a great care of pulling it too far out because of disordering the adhering Vessels within ... then either tie the Veins and Arteries with untwin'd Thread, but strong, and in three or four Places ... and anointing the Ends of the Vessels ... with Balsam ... or else sear off the Vessels and anoint them with the Juice of Sengreen and Plantain beaten with Whites of Eggs ... swath his Belly warm, and lay him upon his left side in Straw. ... The next day if there seems to lye any clotted Blood in the Abdomen ... out of a Glisterpipe ... inject half a Pint of Decoction of Barley with Honey of Roses and Red Sugar till you have wash'd out the clotted Blood.
\end{abstract}

One of Wren's signed anatomical drawings, in colour (Plate I), has been found recently in the Wellcome Institute of the History of Medicine in London, by the Director, Dr. Noël Poynter. It shows a section of small intestine which has been opened to reveal a haemorrhagic ulcer of the type described by Willis in his work on 'Putrid Feaver' as 'little ulcers and exudations and flowings forth of the Blood'. Willis was seeing typhoid patients during the years that Wren assisted him, and it may be that there were many more drawings of pathological subjects, by Wren, than this single example-the only one known to me.

It was in the same year, 1663, that Wren joined the first medical research 'team' deliberately assembled in Britain. Dr. Thomas Willis, Sedleian Professor of Natural Philosophy, decided to find out more about the structure of the human brain, in the hope of understanding man's psychological processes. His assistants were Wren, Richard Lower and Millington, all products of Westminster School. Millington was to succeed Willis in his chair eventually. During the spring of 1663 Wren drew the illustrations for much of Willis's great book Cerebri Anatome. These drawings set a new standard of excellence in biological work. That of the base of the brain shows the first accurate picture of what has ever since been called 'the Circle of Willis'-that great pressure regulator and safety-valve in the arterial supply to the brain. (See fig. 2.)

While Wren was designing the Sheldonian Theatre at Oxford in 1663 he was doubling as Willis's trusted dissector. John Fulton believed that Wren had a major part to play in the recognition of the life-saving function performed by 'the Circle of Willis'since his illustration is better than Willis's explanation of it. Willis was most forthright in giving credit to his team, and notes in the preface of his great work that ' $I$ made use of the Labours of the most Learned Physician and highly skilful Anatomist, Doctor Richard Lower, for my help and Companion, the edge of whose Knife and Wit I willingly acknowledge to have been an help to me for the better searching out both the frame and offices of before hidden Bodies.' Then he generously turns to Wren and Millington, saying: 'Dr. Wren was pleased out of his singular humanity, 


\section{The Bio-medical Pursuits of Christopher Wren}

wherewith he abounds, to delineate with his own most skilful hands many figures of the Brain and Skull, whereby the work might be more exact'. Wren's drawings were appreciated at home by Lower, and abroad by Nicolaus Stensen. Lower wrote in a letter in June of 1663: 'Dr. Wren hath drawn most excellent schemes of the brain, and the several parts of it . . . and next week he will have finished the scheme of the eighth pair of nerves, and then all the work is at an end'. In Paris, Stensen was soon discoursing to $M$. Thévenot's fashionable circle on the anatomy and supposed physiology of the brain, and said: 'The best Figures of the Brain are those of Willis'. This was high praise coming from the hypercritical Stensen, himself a student prodigy in anatomy, and like Wren, interested in the muscles. Robert Hooke comments in a letter to Boyle on the careful and detailed drawings made by Wren for the group of 'neurologists'. Dr. John Plot in his Natural History of Oxfordshire refers to the aid given Willis by 'the deservedly famous Sir Christopher Wren'.

The first neurological research team was not satisfied with anatomical description alone. They proceeded to physiological demonstration, recalling to mind the marvellous saying of Sherrington's hero, Jean Fernel: 'Anatomy is to physiology what geography is to history: it gives the setting for the events'. Thus Lower writes of their team's labours: ' . . . if three arteries were quite obstructed, the fourth would convey blood into all parts of the brain and cerebellum, sufficient enough for life and motion. And to confirm this, this week we took a young spaniel and tied both carotid arteries in the neck very fast and close with silk, and the dog was not at all altered by it, but continued very lively and brisk. . . Again, Lower mentions the use of coloured fluids to prove the collateral circulation afforded to the brain through the arterial circle of Willis-something which Wren's early work on intravenous injection had presaged.

For Wren, to study the anatomy of the eye was to study Nature's architecture. He dissected the eye, and 'exactly measur'd and delineated the Spheres of the Humors in the Eye, whose Proportions one to another were only guess'd at before . . . . He contrived an artificial Eye, truly and dioptrically made-(as large as a Tennis-Ball) representing the picture as Nature makes it: the Cornea and Crystalline were glass, the other Humours Water. He took an exact Survey of a Horse's Eye, measuring what the Spheres of the Crystalline and Cornea were, and what the Proportions of the Distances of the Centers of every Sphere were upon the Axis.' As late as 1682 we find Wren, when President of the Royal Society, commenting on communications concerning the anatomy of the eye and of refractive errors.

About the same time Wren began to make what must be among the earliest drawings of minute bodies enlarged by the microscope. We learn of the existence of this pioneer work by Wren through the quaint introduction to Micrographia written in 1665 by Robert Hooke:

By the Advice of that excellent Man, Dr. Wilkins, I first set upon this Enterprize [Micrographia, or Physiological Descriptions of Minute Bodies made by the Help of magnifying Glasses] yet still came to it with much Reluctancy, because I was to follow the Footsteps of so eminent of Person as Dr. Wren, who was the first that attempted anything of this Nature: whose original Draughts do now make one of the Ornaments of that great Collection of Rarities in the King's Closet. This Honour which his first Beginnings of this kind have received, to be admitted into the most famous Place of the World, did not so much incourage, as the Hazard of coming after Dr. 


\section{W. C. Gibson}

Wren did affright me; for of him I must affirm, that since the Time of Archimedes, there scarce ever met in one Man, in so great a Perfection, such a mechanical Hand, and so philosophical a mind.

This surely is high praise from a competitor!

The reading of letters from Leeuwenhoek to the Royal Society on microscopic matters usually brought forth discussion by Wren. It appears from Birch's History of the Royal Society that Leeuwenhoek was, in 1683, writing to Wren 'concerning generation from an animalcule, not an egg; the muscles of a flea ... the sting and wings of a gnat and its feathers'. Investigating the microcosm with Wren were such notable investigators as Dr. Croone, and Dr. King who was examining 'the globules of blood'. Wren had been interested in microscopes from an early date, for Hartlib, in 1655, credited Mercator with telling him that Wren had 'brought a great perfection into microscopes to make them multiply exceedingly, and geometrically to measure things in them'. In 1657 Walter Charleton wrote that the Oxford Club had: ' . . . microscopes that magnify the dimensions of minute and otherwise undiscernible bodies, even to an incredible rate, and bring the sight to a familiar acquaintance with the shapes of not only whole small flies and other insects, but also the smallest part of them'. Such efforts prompted Joseph Harrington to accuse the Oxford Club of being: 'good at two things-at diminishing a Commonwealth and at multiplying a louse'. Matthew Wren, Christopher's cousin, denied that the group of scientists was merely examining 'little animals' but measuring them-thus persuing 'a limbe of Mathematiques'. Dr. Margery Purver quotes a contemporary as saying of these experiments: 'The author of them was Christopher Wren, and that his drawing of magnified flies, fleas and lice were seen with Delight and Instruction by all Strangers; and not only so but have been received with applause by Foreign Princes'. Nevertheless, Robert South, the Public Orator at Oxford, could not let the matter rest, and at the opening of Wren's Sheldonian Theatre, in 1669, said that the Royal Society could 'admire nothing except fleas, lice and themselves'. He seemed oblivious to the fact that the architect of this new centre for Congregation exercises too rowdy for St. Mary's Church, was himself a prime mover in the new Society.

Circulation and respiration were of continuing interest to Wren. Of one meeting of the Royal Society in 1678 his biographer, Elmes, reports:

\footnotetext{
... a conversation arose upon the causes of the motion of the muscles, and how far the air taken in by the lungs might contribute towards muscular motion. Mr. Henshaw observed, that the divers for sponges and corals at Samos could hold their breath for three quarters of an hour; and mentioned his design of dissecting an otter, in order to inquire into Mons. Des Cartes' assertion concerning the foramen ovale, by which the blood of otters was supposed to pass from one ventricle of the heart to the other, without passing through the lungs; and thence it was supposed that there was less need of the motion of the lungs or breathing, since it was thought that the great use of the motion of the lungs was for making the blood pass through them. But against this, he alleged, that, in his opinion, the otter had no foramen ovale; which Sir Christopher Wren positively asserted, having dissected and examined an otter for that purpose. Sir Christopher, however, related, that the seal which was in St. James's park had muscles, by which it could contract and dilate its nostrils, and by such means sink itself, and lie at the bottom of the pool made for him, for a great while longer; and that it could eat its food at the bottom of the river.
}

At another meeting, presided over by Sir Christopher, in 1682, the significance of 


\title{
The Bio-medical Pursuits of Christopher Wren
}

the pulse in humans was discussed. After swearing in Flamsteed the astronomer as a Member, and describing the disposal of Chelsea College on behalf of the Society, Wren mentioned the practice of Chinese physicians:

\begin{abstract}
... he observed, that they were extremely curious about feeling the pulse of the patient, examining the beating thereof, not only in the wrist, but in various other parts of the body, by which they pretended to make discoveries of the disease; and he was of the opinion, that the ancients might know and make more use of the information of the pulse than our modern physicians of Europe; and that there might be more in Galen's curiosity about the pulse than was generally understood. He also conceived, that there might be somewhat even in the motion of the parts of the artery itself; for it is very visible in living objects, that the artery hath a peculiar muscular motion of its own, distinct from the pulse of the heart; and that, by dissecting, it appeared plainly made up of three sorts of muscular coats; the innermost of them having long fibres, the outermost round fibres, and the middlemost diagonal or tubical fibres.
\end{abstract}

Wren had a sharp eye for isolated biological phenomena from which he could develop a generalized theory. On 12 April 1682, while presiding at a meeting of the Royal Society, he discussed 'the transformation of creatures by means of the qualifications of the place wherein they are fostered; he related that he had observed in a garden made out of the ruins of an old building, that the leaves of all the plants became speckled and striped, and that the same plants, being transplanted thence to another place, continued for some time to be striped and speckled . . . Obviously, trace elements in the soil were as active then as now!

There was a certain pragmatic hard-headedness about Wren to be seen, for instance, as he reported to the Society on Borelli's book De Motu Musculorum. He stated 'that the author had been very elaborate and ingenious in his inquiries into that subject, but seemed to be much mistaken in several things that he asserted; particularly as to the motion of a horse, and in the strength of the motion of a muscle; for that, according to his calculation of the strength, it was impossible that the tendons of several muscles could sustain such a force, though they should be as strong as a piece of iron of the same dimensions.'

Occasionally, the telegraphic condensation practised in reporting Royal Society meetings leaves us wondering about the real meaning of some of Wren's communications. Thus he reported upon 'a strangely diseased boy, at Oxford, who had a consumption of the bones about his head, which bones he pulled out in fragments, some single one of which weighed an ounce. Although he was born of healthy parents, and been healthy himself till of late. Some members inquired how the bones pulled out were coloured; others suggested that information should be desired what nurse the boy had'. Both Wren and his colleague in the Oxford 'Brain Research Institute' Dr. Millington, were asked to provide further data.

After discussing at the Royal Society Dr. Tyson's dissection of a porpoise, Wren was asked to treat with the authorities on 'procuring the bodies of such exotic animals as should die in St. James's park, for the purpose of being dissected and described'. Wren actually set up a committee on Anatomy when he served as President of the Royal Society.

Embryology fascinated him, as it had his teacher Scarburgh, and Scarburgh's teacher Harvey. He was asked to report to the Society on 'the apparatus, and progress which he had made in the experiment of hatching eggs by the equal and moderate 


\section{W. C. Gibson}

heat of a lamp, in order to prosecute the experiment, which was said to have been so far advanced, as that thereby blood was produced in eggs'. On another occasion Wren related 'that ... he had, nearly twenty years before ... upon the dissecting of eels, found them to be viviparous, having several times taken the young ones out alive ... . At a subsequent meeting (Leeuwenhoek's observations on the generation of eels and insects being mentioned), Sir Christopher related that the young eels which he had formerly taken out of the old ones were about the length and bigness of pins; that he had taken out of lobster's eggs a lobster perfectly shaped, with claws, etc; and that water newts, dissected at the proper season of the year, have young ones perfectly formed within them.

In the vast subject of nutrition Wren also had an interest. Once while presiding at the Royal Society he remarked: 'that it was of late years found, that the blacks, who feed only on potatoes, were apt to die of dropsy; and that therefore the planters had found it necessary to allow them milk and bread, which prevented it'. 'The President thence observed, that it was necessary, that all wholesome food should have oils: that most roots wanting oil are not of themselves good nourishment: and that in Ireland, where the people feed much on potatoes, they help themselves by drinking milk soured, to make the potatoes digest the better'.

Not only did Wren design Chelsea Hospital 'for the comfortable maintenance of maim'd and super-annuated soldiers'; he also wrote the rules. The diet which he prescribed contained 'twelve ounces of meat daily, two loaves of bread, one quarter of a pound of cheese, two quarts of beer, and herbs proper and sufficient for the Porridge in the Winter Season'. (Wren's hand is to be seen at Greenwich Hospital also.) In addition he saw to it that a Physic Garden with fruit trees and 'physical herbs' was located beside 'the Apothecary's Laboratory'. He would not allow the burial ground to be placed near the church, and preferred memorial grounds 'for the Dead, and ... good air and walks for the Living'.

It is scarcely likely that anything new can be added concerning Wren's rebuilding of St. Paul's Cathedral. However, Wren's clinical method of looking at thingsdiagnosis first, to be followed by rational therapy-was the secret of his success in this most difficult undertaking. He described the problem by saying: 'Having shown in part the deplorable condition of our patient, we are to consult of the cure, if possible art may affect it. And herein we must imitate the physician, who when he finds a total decay of nature, bends his skill to a palliative to give respite for a better settlement of the estate of the patient.'

In conclusion, I think we would all agree with Richard Steele's view that Wren was 'one of the most accomplished and illustrious characters in history'. The Warden of my college at Oxford, the Hon. H. A. L. Fisher, used to refer to him as 'possibly the greatest Englishman since Shakespeare'. Considering his biological interests, especially, we might conclude that Wren was, in fact, the British Leonardo, and I hope a fit subject for this Monckton Copeman Lecture.

\section{BIBLIOGRAPHY}

BIRCH, Thomas, History of the Royal Society of London, London, A. Millar, 1756-7, 4 vols. ChANCE, Burton, 'Charles Scarborough, an English educator and physician to three kings', Bull. Hist. Med., 1942, 12, 274-303. 


\section{The Bio-medical Pursuits of Christopher Wren}

Cole, F. J., 'The History of Anatomical Injections', Studies in the History and Method of Science, ed. Charles Singer, Oxford, Clarendon Press, 1921, vol 2.

Cushing, Harvey, The Life of Sir William Osler, London, Oxford University Press, 1940.

Dean, C. G. T., The Royal Hospital, Chelsea, London, Hutchinson, 1950.

Elmes, James, Memoirs of the Life of Sir Christopher Wren, London, Priestley \& Weale, 1823.

Frankin, K. J., The Circulation of the Blood, Oxford, Blackwell, 1958.

Franklin, K. J., De Venarum Ostiolis (1603) of Hieronymus Fabricius of Aquapendente, Springfield, Ill., C. C. Thomas, 1933.

Girbert, William, De Magnete, London, Excudebat Petrus Short, 1600.

Gibson, William C., Young Endeavour (introduction by Sir Henry Dale), Springfield, Ill., C. C. Thomas, 1958.

Gunther, R. T., Early Science in Oxford, London, Oxford University Press, 1920 et seq.

Hollander, Eugen, Die Medizin in der Klassichen Malerei, Stuttgart, F. Enke, 1903.

KeEVIL, J. J., 'Sir Charles Scarburgh', Ann. Sci., 1952, 8, 113-21.

KeYNes, G., A Bibliography of Dr. Robert Hooke, Oxford, Clarendon Press, 1960.

Keynes, G., The Life of William Harvey, Oxford, Clarendon Press, 1966.

Purver, Margery, The Royal Society, Concept and Creation, Cambridge, Mass., M.I.T. Press, 1967.

Robi-Smith, A., 'Harvey at Oxford', Oxford Med. Sch. Gaz., 1957, 12, 70-76.

SherRIngton, C. S., The Endeavour of Jean Fernel, Cambridge University Press, 1946.

Sherrington, C. S., Man on His Nature, Cambridge University Press, 1940.

SPRAT, Thomas, History of the Royal Society, ed. by Jackson J. Cope and Harold W. Jones, London, Routledge \& Kegan Paul, 1959.

Stensen, N., A Dissertation on the Anatomy of the Brain, preface and notes by Edv. Gotfredsen, Copenhagen, Nyt Nordisk Forlag, 1950.

WILKINs, JoHN, Discourse Concerning a New World, 1636.

Willis, Thomas, Cerebri Anatome, 1664, Montreal, McGill University Press, 1965 (Reprint edited by William Feindel, M.D. for the tercentenary of the original).

Wren, C., 'Bicentenary Memorial Volume', Royal Institute of British Architects, London, Hodder \& Stoughton, 1923.

Wren, S., Parentalia, London, 1750. 